\title{
Nature Connectedness Levels of Teachers who Received Trekking Training with Mixed Research Approach
}

\author{
Burak Kural1 ${ }^{*}$, Zafer Dogru², Gucluozenc3 \\ 'Department of Sport Science, Trabzon University, Trabzon, \\ Turkey \\ ${ }^{2}$ Department of Sport Science, Hitit University, Çorum, Turkey \\ ${ }^{2}$ Department of Sport Science, Izmir Demokrasi University, Izmir, \\ Turkey
}

Study Area: Trabzon, Turkey

Coordinates: $41^{\circ} \mathrm{oo} ' 18$ ? N; $39^{\circ} 43^{\prime 21}$ ? E

Key words: Mountaineering; Outdoor sports, Recreation Sports

\section{Abstract}

The research is based on an exploratory sequential design, one of the mixed-method designs. In order to determine teachers' level of connectedness to nature, M.N.E (Ministry of National Education) within the scope of in-service training, the "Connectedness to Nature Scale" was applied to 65 teachers who received trekking (summer) training trainers in Aksaray province. Semi-structured interviews were conducted with 20 teachers selected by random sampling method from among the teachers who participated in the scale. It was seen that teachers' level of commitment to nature is high. Further, the teachers' level of connectedness to nature did not show a significant difference as per the gender and professional service life variables, but there was a signif icant difference according to the variable of age and school type. It has been determined that as the age of the teachers' increase, their level of connectedness to nature increases. In the qualitative part of the study, it was concluded that teachers feel freer, find peace and are a part of nature when they are in nature. It has also been concluded that the biggest responsibility in nature is not to harm and protect nature.

friendly behaviors, an emotional connection to nature, conscious awareness. It is thought that the concept of connectedness to nature explains the experience-based bond of individuals, and the phenomenon of emotional bonding to nature is important in gaining environmentally friendly behaviors Mayer \& Frantz (2004). Therefore, it is aimed to investigate the possible effects of this concept related to nature and outdoor activities with trekking, which has an important place among nature sports activities. In the selection and execution of the research subject, it was taken into consideration that the nature trekking sport is differently intertwined with nature and can be a solution to the problems faced today. The purpose of this research; is to determine the level of connectedness to nature and their views on nature devotion of teachers participating in the trekking (summer) educational training institution. For this purpose, the following questions were sought:

- What are the average scores of teachers in the general and subdimensions of the scale of connectedness to nature?

- Do teachers' level of connectedness to nature differ significantly according to their gender, age, school type, and professional service time?

- What are the teachers' views about connectedness to nature?

*Corresponding Author: burakkurall@gmail.com 


\section{Methodology:}

In this study, an explanatory sequential design, which is one of the mixed research models, was used to examine the level of connectedness to nature and the views of the teachers who attended the trekking (summer) training course. The purpose of this design is to clarify the relationships obtained with quantitative data by applying the qualitative step. In this direction, quantitative data were collected first, and then qualitative data were collected, and the collected data were interpreted to explain the quantitative results (Creswell \& Clark, 2014). In the quantitative phase of the study, the scanning model was used to determine the level of connectedness of teachers to nature and to examine whether there is a significant difference between connectedness to nature and various variables. In the qualitative phase of the research, the case study model, one of the qualitative research methods was used to examine the teachers' level of connectedness to nature and their views.

Since the studies conducted with the mixed research approach include quantitative and qualitative data collection stages, they are carried out with more than one research group. The sample group in the quantitative phase of the research; was created with the "appropriate sampling" method due to its easily accessible and adequately representative characteristics of the universe (Gall et al., 2007).

In this direction, it consists of a total of 65 teachers, 32 women and 33 men, who participated in the trekking (summer) trekking training course that is organized within the scope of the Ministry of National Education in-service training on 18-22 November 2019 in Aksaray.

The sampling group of the research in the qualitative stage consists of 20 teachers who were selected by random sampling method, considering gender and branches. Information about demographic characteristics of the teachers' who make up the research group: In terms of age variable, most participants are in the age range of $31--35$ $(35.8 \%)$. It is observed that $24(36.9 \%)$ of the participants are primary school teachers, $22(33.8 \%)$ are teachers working in secondary schools, and $19(29.2 \%)$ are teachers working in high schools. Considering the distribution of the participants in terms of off ice, $46.2 \%$ have a seniority of $1-10$ years, $47.7 \%$ of them $11-20$ years, and $6.2 \%$ of them 21 years or more.

Data collection tools consist of three parts. The first section includes personal information, the second section includes a quantitative data collection tool, and the third section includes an open-ended question form.

Connectedness to Nature Scale: In the quantitative phase of the study, the data were collected through the "Connectedness to Nature Scale (CNS)" which is developed by Mayer \& Frantz (2004) and adapted into Turkish by Bektas et al., (2017). The scale, which was developed to measure individuals' experience-based and emotional connectedness to nature, consists of two sub-dimensions (integration with nature and part of nature) and 8 items.

Structured Interview Form: In the qualitative phase of the study, data were collected through a semi-structured interview form. The semi-structured interview form was prepared by considering the dimensions and items of the quantitative measurement tool to determine the underlying reasons for the quantitative findings obtained. During the preparation of the form; the open-ended questions took their final form by benefiting from trial interviews and expert lecturers' opinions.

The quantitative data obtained in the study were analyzed using the SPSS 22 package program. In the normality analysis of the data set: Kolmogorov Smirnov test results $(\mathrm{p}<.05)$, skewness and kurtosis values of the distribution were examined, histogram and Q-Q plot graphics were analyzed (Çokluk et al., 2010). After these analyzes, nonparametric statistics were used because the data did not meet the parametric test conditions. In the analysis of the obtained data, descriptive statistics such as arithmetic mean, standard deviation, max, and min were made. Later, the Mann-Whitney U test was used for paired comparisons of teachers' level of connectedness to nature, and the Kruskal Wallis $\mathrm{H}$ test was used for more than two comparisons. Mann-Whitney U test was conducted to find out where the difference comes from. The qualitative data obtained in the study were analyzed with the descriptive analysis method. The content analysis is aimed to reach the concepts and relationships that can explain the factors affecting teachers' connectedness to nature. (Yildirim \& Simsek, 2013).

\section{Results:}

In the first part, the analysis findings of teachers' connectedness to nature and the analysis findings according to the variables of gender, school type and professional service are presented.

Table-1: Descriptive Analysis Results of the Scores that Teachers got from the Connectedness to Nature Scale

\begin{tabular}{llllll}
\hline Factors & $\mathrm{N}$ & Min & Max & $\mathrm{X}^{-}$ & Ss \\
\hline Part of Nature & 65 & 21 & 30 & 27.96 & 2.17 \\
Commune with Nature & 65 & 5 & 10 & 9.04 & 1.35 \\
Overall of the scale & 65 & 27 & 40 & 37.01 & 3.10 \\
\hline
\end{tabular}

Table-2: Results Regarding to Teachers' Connectedness to Nature and its Sub-Dimensions According to Gender Variable

\begin{tabular}{llllllll}
\hline Factors & Gender & $\mathrm{N}$ & $\begin{array}{l}\text { Rank } \\
\text { Average }\end{array}$ & $\begin{array}{l}\text { Rank } \\
\text { Sum }\end{array}$ & $\mathrm{p}$ \\
\hline Part of & Female & 32 & 33.72 & \multicolumn{1}{l}{1079.00} & 505.000 & .756 \\
Nature & Male & 33 & 32.30 & 1066.00 & & \\
Commune & Female & 32 & 32.36 & 1035.50 & 507.500 & .762 \\
with Nature & Male & 33 & 33.62 & 1109.50 & & \\
Overall of & Female & 32 & 33.27 & 1064.50 & 519.500 & .910 \\
the scale & Male & 33 & 32.74 & 1080.50 & &
\end{tabular}


It is seen that the teachers' mean scores of connectedness to nature are above the middle level (Table-1).

There was no significant differentiation between being part of nature in terms of gender, integration with nature and in general of the scale of the teachers who participated in the study (Table-2).

Table-3: Kruskal Wallis H Test Results according to age variable of teachers' level of connectedness to nature.

\begin{tabular}{|c|c|c|c|c|c|}
\hline Factors (Sd; & $\mathrm{X}_{2}$; & p; Signif & ant Differer & & \\
\hline Age & $\mathrm{N}$ & Rank Av. & Age & $\mathrm{N}$ & Rank Av. \\
\hline Part of Natur & e (SD & $X_{2}=14.588$ & $\mathrm{P}=.006^{*}$; Sig. $\mathrm{C}$ & ff.- 41 & $15>31-35)$ \\
\hline 26-30 ages & 10 & 45.00 & 31-35 ages & 24 & 26,02 \\
\hline 36-40 ages & 16 & 27.16 & $41-45$ ages & 11 & $45 \cdot 73$ \\
\hline$>46$ ages & 4 & 33,25 & & & \\
\hline Commune w & th $N$ & ure & $\left(\mathrm{SD}=4 ; \mathrm{X}_{2}=4\right.$ & $97 ; P$ & 355) \\
\hline 26-30 ages & 10 & 38.90 & $-31-35$ ages & 24 & 29.56 \\
\hline 36-40 ages & 16 & 31.31 & $41-45$ age & 11 & 39.45 \\
\hline$>46$ ages & 4 & 27.88 & & & \\
\hline Overall of th & Sca & $\left(\mathrm{SD}=4 ; \mathrm{X}_{2}=\right.$ & $.205 ; \mathrm{P}=.016^{*}$; & ig. di & $-41-45>$ \\
\hline 26-30 ages & 10 & $44 \cdot 30$ & 31-35 ages & 24 & 26.85 \\
\hline 36-40 ages & 16 & 27.81 & 41-45 age & 11 & 44.50 \\
\hline$>46$ ages & 4 & $29 \cdot 50$ & & & \\
\hline
\end{tabular}

As per the results of the analysis, a significant difference was observed in favour of teachers aged 41-45 between the part of nature sub-dimension and the teachers aged between 41-45 and 31-35 in general in the scale (Table-3).

Table-4: Kruskal Wallis H Test Results according to the branch variable of teachers' level of connectedness to nature.

\begin{tabular}{|c|c|c|c|c|c|}
\hline $\begin{array}{l}\text { Factors } \\
\text { School Type }\end{array}$ & $\mathrm{N}$ & Rank Ave. & School Type & $\mathrm{N}$ & Rank Ave. \\
\hline \multicolumn{6}{|c|}{ Part of Nature $\left(\mathrm{Sd}=2 ; \mathrm{X}_{2}=10.576 ; \mathrm{p}=.005^{*} ;\right.$ Sig. .Diff. $=$ Class $>$ social studies $)$} \\
\hline Class & 24 & 39.92 & \multirow[t]{2}{*}{ Social Studies } & \multirow[t]{2}{*}{22} & \multirow[t]{2}{*}{22.86} \\
\hline Science & 19 & 36.00 & & & \\
\hline \multicolumn{6}{|c|}{ Commune with Nature $\left(\mathrm{Sd}=2 ; \mathrm{X}_{2}=5.285 ; \mathrm{p}=.071\right)$} \\
\hline Class & 24 & 38.90 & \multirow[t]{2}{*}{ Social Studies } & \multirow[t]{2}{*}{22} & \multirow[t]{2}{*}{31.43} \\
\hline Science & 19 & $27 \cdot 37$ & & & \\
\hline \multicolumn{6}{|c|}{ Overall of scale $\left(\mathrm{Sd}=2 ; \mathrm{X}_{2}=7.983 ; \mathrm{p}=.018^{*} ;\right.$ Sig. Diff. $=$ Class $>$ social studies $)$} \\
\hline Class & 24 & 40.96 & Social Studies & 22 & $25 \cdot 59$ \\
\hline Science & 19 & 31.53 & & & ${ }^{* *} \mathrm{p}<0.01$ \\
\hline
\end{tabular}

This finding shows that teachers' branches influence their level of connectedness to nature. Primary school teachers' part of nature $\left(\mathrm{X}^{-}=39.92\right)$, the scale's overall $\left(\mathrm{X}^{-}=\right.$ 40.96) mean scores are significantly higher than social studies teachers $\left(\mathrm{X}^{-}=39.92\right)\left(\mathrm{X}^{-}=25.59\right)$, and the difference has been determined to be in favour of primary school teachers. It is seen that the scores the teachers got in the commune with nature sub-dimension do not make a signif icant difference in terms of the department variable.

As per Table- 5 the teachers' level of connectedness to nature it is determined that there was no difference between the part of nature, integration with nature in dimensions and scale total.

It is seen that the teachers who receive trekking training, experience different emotional states about being in nature.
Accordingly, the most frequently repeated opinion among the opinions about what teachers express about being in nature and spending time in nature is feeling free $\mathrm{f}(\mathbf{2 2})$. Teacherviews on this are as follows:

"Being in nature gives a feeling of endless freedom. Nature gives liberty even to dumb animals, says Tacitus. I am also one of those animals" $T_{34}$

Table-5: Kruskal Wallis H Test Results as per the professional service variable of teachers' level of connectedness to nature.

\begin{tabular}{|c|c|c|c|c|c|}
\hline \multicolumn{6}{|c|}{ Factors (Sd; X2; $\quad$ p; Significant Difference) } \\
\hline Type & $\mathrm{N}$ & Rank Av. & Age & $\mathrm{N}$ & Rank Av. \\
\hline \multicolumn{6}{|c|}{ Part of Nature $\left(\mathrm{SD}=2 ; \mathrm{X}_{2}=2.429 ; \mathrm{p}=.297\right)$} \\
\hline 1-10 years & 30 & 36.60 & $11-20$ years & 31 & \multirow[t]{2}{*}{$29 \cdot 31$} \\
\hline$>21$ years & 4 & 34.63 & & & \\
\hline \multicolumn{6}{|c|}{ Commune with Nature $\left(\mathrm{SD}=2 ; \mathrm{X}_{2}=2.502 ; \mathrm{p}=.286\right)$} \\
\hline 1-10 years & 30 & $29 \cdot 77$ & \multirow[t]{2}{*}{ 11-20 years } & 31 & \multirow[t]{2}{*}{35.10} \\
\hline \multirow{2}{*}{\multicolumn{6}{|c|}{ Overall of the scale $\left(\mathrm{SD}=2 ; \mathrm{X}_{2}=.500 ; \mathrm{p}=.779\right)$}} \\
\hline & & & & & \\
\hline \multirow[t]{2}{*}{$1-10$ years } & 30 & $33 \cdot 37$ & $11-20$ years & 31 & 31.90 \\
\hline & & \multicolumn{4}{|c|}{$>21$ years $438.75 * \mathrm{p}<0.05^{* *} \mathrm{p}<0.01$} \\
\hline \multicolumn{6}{|c|}{$\begin{array}{c}\text { Table } 6 . \text { Views on what it means to be in nature and to spend } \\
\text { time in nature. }\end{array}$} \\
\hline \multicolumn{3}{|l|}{ Codes } & \multicolumn{3}{|c|}{ Frequency } \\
\hline \multicolumn{3}{|l|}{ Feeling free } & \multicolumn{2}{|l|}{22} & \\
\hline \multicolumn{3}{|c|}{ Peace of mind } & \multicolumn{2}{|l|}{15} & \\
\hline \multicolumn{3}{|l|}{ Being happy } & \multicolumn{2}{|l|}{11} & \\
\hline \multicolumn{3}{|c|}{ Finding yourself } & \multicolumn{2}{|l|}{9} & \\
\hline \multicolumn{3}{|c|}{ Feeling energetic, strong } & \multicolumn{2}{|l|}{3} & \\
\hline \multicolumn{3}{|l|}{ Total Views } & \multicolumn{2}{|c|}{60} & \\
\hline
\end{tabular}

Another view that has the most frequent frequency of teachers' expressions about being in nature and spending time in nature is giving peace $\mathrm{f}(15)$. The opinions of the teachers with codes $\mathrm{T}_{39}$ and $\mathrm{T}_{42}$ regarding this issue are as follows: "Being in nature makes me feel peace and enjoying life". "Nature is where peace begins for me". This is followed by happiness $f(11)$ and self-discovery $f(9)$. The least expressed opinion by teachers about being in nature is feeling energetic/strong $f(3)$ (Table 6). The opinions of the teacher regarding these situations are as follows:

"Being in nature gives me energy. My emotions are changing in a positive way. It gives me the chance to meet people with whom I share the same taste. (T39)

Table 7. Opinions about the meaning of commune with nature / relate to nature.

\begin{tabular}{ll}
\hline Codes & Frequency \\
\hline Being a part of nature & 8 \\
Finding / understanding yourself & 7 \\
Quality life & 5 \\
Adding meaning to life & 3 \\
Awareness of nature & 3 \\
Gaining willpower & 2 \\
Taking responsibility & 1 \\
Total Views & 29 \\
\hline
\end{tabular}

When the data presented in Table 7 are examined; It is seen that teachers make different descriptions of the 
meaning of integration with nature. It has been determined that the participants put forward different alternatives due to their hiking and camping in nature. It is seen that most of the teachers $\mathrm{f}$ (8) expressed the integration with nature as being a part of nature. This view is followed by selfdiscovery/understanding $\mathrm{f} \mathrm{(7)} \mathrm{and} \mathrm{Quality} \mathrm{life} \mathrm{f}$ (5). The opinions of the teachers regarding these situations are as follows:

"Human is never separate from nature, he is a whole with nature. It is impossible for me to see human beings as separate from nature, human is a part of nature. $T_{4} 8$

"I find the opportunity to realize how small beings we are in the face of nature. T64

"It's like walking from the boring and depressing life of cities to the garden of paradise to happiness. T42

In addition, the least expressed opinion by teachers about the meaning of integrating with nature; is taking responsibility. About this situation, T16 stated that; "It is taking responsibility for the future and future generations."

Another question asked teachers is "What kind of responsibilities do you think you have on life and in natural life?". In Table-8, the opinions of the teachers about what life in nature or the responsibilities to have in natural life are given.

\section{Discussion and Conclusion:}

In the study: It was determined that the average score that teachers obtained from the scale of connectedness to nature is above the middle level. Considering the subdimensions of the scale; It has been determined that there is a commitment above the middle level in the dimension of "part of nature" and "commune with nature". According to these findings, it is understood that teachers who take a walk-in nature connect with all living things on earth, understand them, and exhibit environmentally friendly behaviors. In the literature, it is striking that people who interact with nature have a high level of connectedness to nature (Braun \& Dierkes, 2017). In Kamitsis \& Francis (2013) studies with individuals aged between 18 and 69 years, Silvas (2013) with children, Karademir (2017) with preservice teachers, with pre-school and pre-school teachers, it was found that their level of dependence on nature was at a medium level. These results seem to support the findings of ourstudy.

It was determined that the teachers who received the hiking trainer training did not signif icantly differ according to their level of connectedness to nature, gender, and professional service. Supporting this finding of the study, Yilmaz \& Olgan (2017) found a similar result in their research to determine the level of connectedness to nature in preschool children, also Derince's (2019) studies on orienteering athletes, and Çelik (2019) in individuals engaged in mountaineering. It is thought that the significant difference in the vocational service variable is related to the transportation infrastructure of the cities where they live.
Age variable positively affects teachers' level of connectedness to nature. The study findings revealed that as the age level increases, the level of connectedness to nature increases. As the age of teachers increases, their connectedness to nature scores increase and this may suggest that their relationships with nature develop based on experience. In the meta-analysis studies of Çelik (2019) mountaineers, Derince (2019) orienteers, Schutte \& Malouff (2018), they found that elderly individuals have higher levels of connectedness to nature compared to young people. This situation is thought to be related to elderly people having more free time. Contrary to these studies, Liefländer et al., (2013) stated that those who are younger are more connected to nature than older ages.

In the present study, it has been determined that teachers' level of connectedness to nature differs significantly according to the branch variable. It has been determined that this significant difference is between class and social studies teachers. When the averages are examined, it was determined that class teachers are more connected to nature than science teachers in terms of part of nature and general of the scale. According to his study about the level of connectedness to nature of teacher candidates, Karademir (2017) determined that there was a significant difference in the total of the scale, and this significant difference was found between class and social studies teacher candidates. This result supports the findings of the research.

In the research, interviews were conducted to determine the teachers' views on their level of connectedness to nature. When the findings of the teachers' concept of being in nature we evaluated; It is seen that teachers frequently express the expressions of feeling free $(f=22)$ and giving peace $(f=15)$ when they are in nature. Therefore, it is noteworthy that hiking or camping in nature affects teachers more psychologically. In their study on individuals who do trekking, Ardahan \& Lapa (2011) found that trekking is quite successful in living a different lifestyle as well as freedom tendency. Silvas (2013) also revealed in his research that feelings such as happiness, peace, excitement, curiosity, joy, freedom, love, and comfort felt by the child while he/she is in nature or while thinking about nature are the result of the child's relationship with nature. Accordingly, it can be concluded that being in nature increases our quality of life or has a significant impact on our lives.

Teachers have frequently stated the expressions of being a part of nature $(\mathrm{f}=8)$ and finding/understanding oneself in nature ( $f=7$ ) as a means of integrating with nature or establishing a relationship with nature. In the literature, the concept expressing the connection between man and nature has been named biophilia (Wilson, 1984). Biophilia is a genetically-based human need that emerges to establish and maintain a connection with life (Kahn, 1997). 


\section{ORIGINAL ARTICLE}

In this direction, this finding of our research showed that there may be a mutual relationship between the biophilic level of the area of teachers' integration with nature.

As a result, it was determined that the level of connectedness to nature of the teachers who received the nature walk trekking training was at a good level and the highest average score the teachers had was the natural part and commune with nature sub-dimension. It has been determined that there is no significant difference in the level of attachment to the nature of male or female teachers, but there is a significant difference in the age factor. It is seen that as the age progresses, the level of connectedness to nature increases. The length of service that teachers spend in their profession does not affect teachers' connectedness to nature. Trekking or camping, which makes an important contribution in terms of psychological health, takes an important place in integrating teachers with nature and feeling that they are a part of nature. Besides, the primary responsibility of teachers who are a part of nature is to protect nature and not to harm it.

\section{References:}

Ardahan, F. \& Yerlisu-Lapa, T. (2011): Outdoor Recreation: Reasons of cycling users and trekkers for outdoor sports and their benef its. Int. J. Human Sci., 8(1):1327-41.

Barton, J., Bragg, R., Pretty, J., Roberts, J. \& Wood, C. (2016): The wilderness expedition: An effective life course intervention to improve young people's well-being and connectedness to nature. J. Experiential Edu., 39(1):59-72.

Bektas, F., Kural, B. \& Orçan, F. (2017): Turkish adaptation of connectedness to nature scale: validity and reliability study. $L$. Physic. Edu. Sports Sci., 11(1).

Braun, T. \& Dierkes, P. (2017): Connecting students to nature-how the intensity of nature experience and student age influence the success of outdoor education programs. Environment. Edu. Res., 23(7):937-949.

Creswell, J.W. \& Plano-Clark, V.L. (2014): Mixed Method Research Design and Execution. (Trans. Dede Y, Demir S. B). 2nd Edition, Pub. by: Ankara:Ani Publishing.

Çokluk, Ö., Sekercioglu, G. \& Büyüköztürk, S. (2012): Multivariate statistics for social sciences: SPSS and LISREL applications (Vol. 2). Pub. by: Ankara: Pegem Academy.

Çelik, O.A. (2019): Investigation of connectedness to nature, mindfulness, self-control levels of individuals dealing with mountaineering. Master's thesis,Anadolu University / Institute of Social Sciences.

Derince, B. (2019): Research of orienteering athletes' commitment to nature. Master's thesis, Inönü University / Institute of Health Sciences.
Ambient Science, 2020: Vol. 07(Sp1); 253-257 DOI:10.21276/ambi.2020.07.sp1.oa34

Dunlap, R.E., Van Liere, K.D., Mertig, A.G. \& Jones, R.E. (200o): New trends in measuring environmental attitudes: measuring endorsement of the new ecological paradigm: a revised NEP scale. J. Social Issues, 56(3):425-442.

Gall, M.D., Gall, J.P., Borg, W.R. \& Mendel, P.C. (2007): Gall, Gall and Borg 'A guide to preparing a thesis or thesis proposal in education for educational research: an introduction' and 'Educational Research Practice'. Pub. by: Pearson Education.

Kahn, P.H. (1997): Developmental psychology and the biophilia hypothesis: Children's affiliation with nature. Developmental Review, 17(1):1-61.

Kamitsis, I. \& Francis, J.P. (2013): Spirituality Mediates The Relationship Between Engagement With Nature and Psychological Wellbeing. J. Environment. Psychol., 36:136-143.

Karademir, Y. (2017): Teacher Candidates' Level of Commitment to Nature and Ethical Attitudes (Doctoral dissertation, Master's Thesis, MuglaSitkiKoçman University, Institute of Science, Mugla.

Liefländer, A.K., Fröhlich, G., Bogner, F.X. \& Schultz, P.W. (2013): Promoting connectedness with nature through environmental education. Environment. Edu. Res., 19(3):370384.

Mayer, F.S. \& Frantz, C.M. (2004): The connectedness to nature scale: A measure of individuals' feeling in community with nature. J. Environment. Psychol., 24(4):503-515.

Nisbet, E.K., Zelenski, J.M. \& Murphy, S.A. (2009): The nature relatedness scale: Linking individuals' connection with nature to environmental concern and behavior. Envi. Behav., 41(5):715-740.

Schutte, N.S. \& Malouff, J.M. (2018): Attention and adherence to nature: A meta-analytical research. Personality and Individual Differences, 127(1):10-14.

Schultz, P.W. (2001): The structure of environmental concern: concern for self, other people, and the biosphere. L. Environment. Psychol., 21(4):327-339.

Silvas, D.V. (2013): Measuring An Emotional Connection To Nature Among Children. Ph.D. Thesis, Colorado State University, Colorado, 89s.

Yildirim, A. \& Simsek, H. (2013): Qualitative Research Method in Social Sciences 1tth Edition, Pub. by: Ankara: Seçkin Publishing: 237-65.

Yilmaz, S. \& Olgan, R. (2017): Investigation of pre-school children's proximity to nature (biophile) levels. Mersin University. J. Facul. Edu., 13(3).

Wilson, E.O. (1984): Biophilia. Pub. by: Boston: Harvard University Press. 